\title{
Thinking with animals
}

\author{
Andreas Roepstorff \\ Department of Social Anthropology, University of Aarhus \\ Moesgaard, DK-8270 Hoejbjerg, Denmark \\ e-mail: etnoroep@au.dk
}

\begin{abstract}
A central claim of biosemiotics is the ascription of semiotic competence to nonhumans. For strange historical reasons, this claim has been quite controversial in much of standard biological discourse. An analysis of ethnographic material from Greenland demonstrates that people regard animals as nonhuman "persons", i.e., as sensing and thinking beings. Like humans, animals are supposed to have knowledge about their environment. Taking this semiotic competence as a fact beyond any doubt enables skilled hunters and fishermen to rely not only on their own interpretation of the environment, but also on the animals' interpretation of their environment. The behaviour of fish, seals, and land animals, meditated by their acknowledged semiotic competence, can thus be interpreted as giving signs about the behaviour, e.g., of whales and icebergs. This a priori ascription of semiotic competence is also apparent in discussions about management and regulation of animals. Rather than discussing whether "the stock" is depleted, much of the discourse among fishermen and hunters focuses on whether animals can be semiotically disturbed by what people are doing.
\end{abstract}

For several decades, a dichotomy between nature and culture has been a backdrop of anthropological theories, whether grounded in materialism, such as cultural ecology and Marxism, or in symbolism, such as structuralism or interpretive anthropology (Descola \& Pálsson 1996). However, in recent years, a general shift of focus in ethnographic studies has questioned the reality of this dualism. Instead of being taken as a given fact, as a background allowing for the interpretation of various phenomena, the highly specific and concrete interpretations of the nature-culture dichotomy in a given context has been put into question (Roepstorff \& Bubandt 2002). 
This development in anthropology and ethnography appears to run parallel with the recent developments in semiotics where, in a similar vein, the nature-culture dichotomy has become an analytical question. In particular, biosemioticians have claimed for more than a decade that it is indeed meaningful to study sign processes outside of the human realm (Sebeok 1988), and in ecosemiotics the question of how sign-processes are mediated between humans and their environment has become the focus of investigation.

Based on ethnographic material from West-Greenland, this paper reexamines Claude Lévi-Strauss' classical statement on the cognitive relationship between humans and animals (Lévi-Strauss 1963).

In moving back and forth between ethnographic descriptions and an analysis that touches on both eco- and biosemiotics, the study attempts to demonstrate how these three perspectives may be fruitfully interrelated in simultaneously calling into question the reality of the nature-culture dichotomy. The analysis demonstrates that embedded in the interactions between humans and animals is a fundamental understanding of the similarities and differences between humans and nonhumans. It is suggested that the choice of a semiotic as opposed to a physical stance towards the nonhuman world is a question inscribed in larger issues of a cosmological nature, and that the distinction between humans and nonhumans is central to how people relate to, and act in, the world.

In his classical study on Totemism, Lévi-Strauss (1963: 69) harshly criticizes the overtly materialist and functionalist explanation of totemism held by the British social anthropologists Malinowski and Radcliffe-Brown. As an alternative, Lévi-Strauss suggests that in totemism, "natural species are chosen not because they are 'good to eat' but because they are 'good to think" (ibid.: 89). Thinking, according to Lévi-Strauss, is nothing mundane. In thinking, animals are not primarily "creatures that are feared, admired, or envied". Instead, "their perceptible reality permits the embodiment of ideas and relations conceived by speculative thought on the basis of empirical observations" (ibid.). The reality of totemism may therefore be "reduced to that of a certain mode of thought. [... Its] image is projected, not received; it does not derive its substance from without. If the illusion contains a particle of truth, this is not outside us but within us" (ibid.: 104).

Lévi-Strauss's claim that the relationship of humans to animals is first of all conceptual and not about proteins avoids a number of problems. However, his understanding of thinking appears to create a 
whole set of new problems to which I will return later. Meanwhile, I will shift my focus to the ethnographic scene.

\section{The scene}

From 1996 to 1998, I conducted a number of ethnographic fieldworks in western Greenland focusing on the relationship between perceptions of nature and management of living resources. A central issue was to examine how the Greenlandic hunters and fishermen related to the animals they pursued. I was mainly interested in marine animals, such as fish, seals, and whales. These animals were generally described as quite sensible beings that would usually try to get what they wanted, e.g., prey and partners, while avoiding what they did not want, such as unpleasant or dangerous things, places, or encounters (Roepstorff 2000, 2002). This representation may not seem very exotic. On the contrary, it should appear very straightforward, and this was also how I found it in the beginning. However, the position entailed some consequences that were both logical and most surprising.

Let me give an example. Economically, the most important species for the Greenlanders I was working with, is the Greenland halibut, a rather large fish of the flounder family. The species is said to be particularly fond of living in places with deep water and active glaciers or large icebergs. Now, active glaciers and icebergs are very beautiful, but they are also very dangerous to be nearby. The combination of a lot of compressed ice (most of which is under water), the ongoing melting, and the strong currents is a very unstable cocktail. Therefore, an iceberg or the front of a glacier may suddenly tip, break into pieces, or literally explode, and this can cause gigantic waves and turbulences. The consequences for anyone nearby, either on the ice or in a boat, may be literally devastating. However, it is in these very hostile places that the Greenland halibut prefers to be, so there may be very good reasons to try to be there if you are a fisherman. In the very same areas, and partly for the same reasons, one may also encounter seals, popping up and down the water between the ice floes. As several of my informants told me, this is a very good sign. Like humans, seals are not particularly fond of being near an iceberg that suddenly explodes. However, every fisherman knows that seals have better ways of knowing whether an iceberg will break than humans. As long as there are seals around, it is considered fairly safe to be there for hu- 
mans as well, but if the seals suddenly disappear, it may, indeed, be time to cut the lines and get going in a hurry.

Some of the explanations claimed for this relationship did not appear very unusual. Seals have a very good sense of hearing. They are constantly in the water, and they are therefore very likely to register, understand, and react to changes in the sounds that the glacier constantly emits. Many fishermen, while being inside their boat, have heard themselves how the constant conglomerate of sounds from the water and the ice may suddenly change shortly before something is going to happen. In knowing the behaviour of icebergs, the Greenlandic fishermen and hunters thus do not only rely on direct observation. The behaviour of seals, meditated by their acknowledged semiotic competence, can routinely be interpreted as giving signs about the behaviour of glaciers and icebergs.

There are several similar instances of the use of the competence and interpretation of a species to get knowledge about something that is invisible to humans. A classical example, first described some 100 years ago, is the relationship between the sudden disappearance of the Greenland halibut and the imminent arrival of Beluga whale that allegedly predates on this fish. When discussing this issue, one of my informants claimed that he knew for a fact that the fish knew about the arrival of the Belugawhale, but it was indeed amazing and peculiar how how the fish could know from a distance that its enemy was on its way.

\section{Animals as nonhuman "persons"}

My observations are quite in accordance with a general finding of anthropological field studies of hunters in the Arctic, namely that animals are considered nonhuman "persons" (Fienup-Riordan 1990: 168). ${ }^{1}$ According to this view, humans and animals are alike in that they are all living beings, and they are all "situated in a field of relations which, as it unfolds, actively and ceaselessly brings form into being: humans as humans, geese as geese, and so on" (Ingold 2000: 51). The notion has two very important and interrelated implications. Firstly, animals are "persons" equipped with consciousness as a con-

${ }^{1}$ Very similar analyses have been given for the Yup'ik Inuits in Alaska by Fienup Riordan, for the North American Indian groups of the Cree (Scott 1996), and for the Ojibwa by Hallowell (Ingold 2000: 90). 
sequence of their being alive (ibid.). Secondly, the relationship of animals and people were traditionally based on complicated exchanges based on the particular "personalities" of each species (Fienup-Riordan 1990: 168).

According to the description above, animals are sensible and sensing beings able to get what they want, such as prey and partners, while avoiding what they do not want, such as unpleasant things, places, or encounters with predators. This account of the nature of animals is hardly controversial. However, claiming that animals are "persons" is likely to appear absurd, perhaps even perverse (Ingold 2000: 90), since in the West, speaking of persons is to tell solely of the thoughts, intentions, and actions of human beings (ibid.). Nevertheless, even in the West, there are several instances where animals are treated like persons. For instance, pets are spoken to, expected to understand, given a name, and perhaps even taken through life cycle rituals, such as burials (ibid.). One may also use the animal's knowledge and senses to find things invisible to humans like one can train a dog to find explosives or drugs. This is not much different from the Greenlanders' use of the seals' behaviour to interpret the ice or the weather conditions. Thus, even in the West, animals may well be thought to be equipped with person-like qualities. However, these examples are the exception that proves the following general rule: to be a person is to be human, and animals can only be persons to the extent that 'humanity' has "'rubbed off' on them through close contact with humans" (ibid.: 91).

To be a person in a Western context implies hence to be touched by culture. Such a view is fully in accordance with the Cartesian dualism of mind vs. body and culture vs. nature. The two semantic axes appear to run more or less in parallel. Mind as well as personhood presupposes that a living being is impregnated with culture.

Of course, the concept of dualism is an abstraction. Nevertheless, the validity of this opposition can be demonstrated by semantic analysis as discussed above In other spheres, similar studies have shown that whole sets of meanings in verbal and nonverbal practice are structured in accordance with a general understanding of personhood as an immaterial mind, which is impregnated with culture, inhabiting a physical body, which is a concretization of nature (Lakoff \& Johnson 1980; Kirmayer 1988).

The traditional Inuit understanding of human existence, by contrast, is not structured in this dichotomy. Inuk, a human being, is rather understood as consisting of timi, usually translated as 'body', of 
tarneq, ${ }^{2}$ usually translated as 'soul', and ateq usually translated as 'name' (Rink 1974; Nuttall 1992; Nuttall 1998: 182). Of these three concepts, the meaning of tarneq is probably the one that is most difficult to grasp, partly because the first missionaries picked on this notion as the translation for the Christian idea of the soul. However, the Christian understanding of an immortal soul, did not comply well with the traditional Greenlandic understanding, as indicated by Crantz who wrote in 1820: "There are indeed some [Greenlanders] who believe, that their soul is not immortal or different from the living principle in other animals; but these are of the most stupid sort" (quoted in Nuttall 1992: 184).

The usual translation of tarneq is soul, mind (Berthelsen et al. 1990). It is generally thought that the word is etymologically connected to tarraq ('shadow', 'reflection') and taarneq ('darkness') (Nuttall 1992: 65), but the matter has not been settled. According to the traditional Greenlandic belief, animals and people alike have a tarneq that is somehow embodied in the timi. In her discussion of the cosmology among the Yup'ik Eskimos in Alaska, Fienup-Riordan (1990: 168) notices that a somewhat similar stem, takar unites people and animals: "The qualities of personhood shared by humans and animals establish the basis for a mutual and necessary respect. Respect is understood in both positive and negative terms. Perhaps the most often used term is takar- ('to be shy of, respectful toward, and/or intimidated by')". However, specialists of Greenlandic etymology are not certain whether and how there is a relationship between the takar among Yup'ik and tarneq in Greenland, ${ }^{3}$ and it is now generally

${ }^{2}$ To complicate matters further, tarneq is sometimes described as being identical with, at times different from anersaaq, 'breath' ('soul') (Nuttall 1992: 65-66; Birgitte Sonne, personal communication). However, for the current discussion, the more subtle distinction between tarneq and anersaaq can be ignored..

${ }^{3}$ The word tarneq consists of the stem tar- (taq-) and the suffix -neq which generally denotes an abstract noun like the English words ending in -ness. Another word using a similar stem is taqippoq (to be shy) that is apparently used both for people and animals. Experts on Greenlandic are, however, not certain whether the stems in tarneq and taqippoq are indeed one and the same and whether it may be related to takar among the Yup'ik. Etymologically, there is probably no direct connection, but the words appear to be part of a complicated semantic field in which unusual transformations are likely to have occurred due to various linguistic taboos (Mike Fortescue, personal communication). In common usage, taqippoq and tarneq are generally not considered to be connected. There may be a semantic link, though, either directly or via the common features of 'shadow' and 'darkness'. If there has been such a link in Greenlandic, it may have been made explicit in the secret language of the angakut 
thought to be impossible to separate the original meaning of tarneq from its later Christian connotations.

Of the three concepts timi, tarneq, and ateq, only the word ateq has traditionally been considered to be uniquely possessed by humans. Naming in Greenland carries a strong social importance. This is not the place to give a full account of the concept, but traditionally as well as today, a child is considered to be linked socially and spiritually to the deceased persons whose names they carry, just as persons with the same name are considered to be somehow connected (Nuttall 1992: 67-69).

Now, if this abstraction is taken to be as real as the Cartesian view in Western thought, we have two very different understandings of the difference between humans and animals. In both cases, humans and animals are distinguished, since humans have something that animals do not have. Cartesian dualism, however, postulates that humans have an immaterial mind in a material and physical body, while nonhumans are nothing but material and therefore they have no mind. According to the traditional Inuit understanding, by contrast, both humans and animals have minds and bodies, although only people have ateq the name (soul).

I do not claim that this abstraction of a "traditional" Inuit understanding is passively being enacted in contemporary Greenland, nor do I claim that Westerners are merely passive reproducers of Cartesian dualism. However, thinking with animals, as I describe it above, appears rather incompatible with a Cartesian dualism but it is well in accordance with a traditional Inuit tri-partite understanding of humans and animals,. We will return to this topic below after a discussion of how the understanding of animals is related to ecological concerns.

\section{Environmental protection as Umwelt protection}

During the last decade, the environmentalist debate has reached Greenland and environmental issues have become a major concern for many. At times, the environmentalist discourse runs counter to ideas about management and protection of "nature" already held locally, but there is at times a strong convergence between local management and nature protection proposals and the environmentalist discourse. How-

(shamans), but this can not be established with certainty. It remains for experts in Inuit languages to pursue this matter further (Robert Petersen, personal communication). 
ever, although there may be some agreement as to the measures, they appear to arise partly from different ways of thinking, as the following two examples may show.

Is gillnet fishing misbehaving?

The deep ice-fjords in Western Greenland have always been favoured as a habitat of the Greenland halibut. The best fishing site is in the vicinity of Kangia, Ilulissat icefjord, a highly spectacular location with the magnificent Jakobshavn glacier, the most productive one of the Northern hemisphere, located in the bottom of the fjord. Since the early 20th century, the halibut has mainly been caught by means of long-lines, but since the 1980's, an intensive gill-net fishery from smaller (30') cutters has begun. Since 1993, based on mathematical modelling, biologists have been calling for a reduction in fishing pressure, initially because it was feared that the stock was directly threatened, later because it was estimated that CPUE (catch-per-unit-effort) could be raised if the fishing pressure was reduced (Roepstorff 1998). Banning the very efficient gillnet fishery was considered to be an efficient measure against overfishing. The proposed ban on gillnets was partly supported by Royal Greenland, a commercial company owned by Greenland Home Rule, who in practice has an almost total monopoly on buying and processing the fish. One of the reasons of this support was that Royal Greenland found out that many fish caught in gillnets were damaged, causing a deteriorated meat-quality in the production line. Hence, both arguments against gillnets are concerned with the body of fish, although for different reasons. While the factory is interested in receiving specimens whose bodies are as unimpaired as possible, the biologists are concerned about an abstract body of the fish, the stock, which is an ideal sum of all the individual specimens (Roepstorff 1998).

Among the fishermen, there has been concern about the gillnets, too. Based on local initiatives, the use of gillnets was banned in certain zones inside the ice fjords. There appears then to be a general agreement on some limitations on the use of gillnets. However, the arguments that I recorded among the fishermen were generally very different from the ones heard from the industry and from biologists.

One of the central concerns discussed among fishermen is the existence of "ghost-nets", that is, gillnets that have been lost, but are still actively fishing in the water. Nets are easily lost when they are set in 
regions of much ice, which is precisely in the zones where gillnet are banned, and the fishermen regularly urge on the municipality to do something to clean the water of lost equipment. Fishery biologists acknowledge that lost nets may continue to fish for a while, but they generally claim that in terms of pure biomass, it is a negligible quantity, since the nets usually get entangled very quickly and will therefore no longer pose any kind of threat to the stock. Among the fishermen, by contrast, there seems to be less concern with the body than with the mind of the fish. In order to understand how this is the case, let us look in detail at another concept.

As shown elsewhere (Roepstorff 2000, 2002), the notion of overfishing is commonly translated as aalisapilunneq in Greenlandic. In contrast to the English concept, aalisapilunneq does not merely describe a technical process affecting an abstract stock, but the word has the morally negative connotation of someone taking more than what one needs. Whereas the arguments of the biologists and of the industry are framed in a discourse concerning "the rational use of a limited body of fish" the fishermen's arguments are embedded in a moral discourse concerning need, waste, and concern for the fish in a very particular way. In a logic where "taking more than one needs" is frowned upon, the possible existence of ghost-nets fishing without satisfying the needs of anyone is, indeed, something evil. Gillnet fishermen claim, on the other hand, that the problem is not related to the technology as such, but rather to the materials being used. Modern materials will not deteriorate in the water, and longlines and gillnets alike may therefore cause problems if they are used without care. That the fishermen's discourse differs from the one of the biologists is, for instance. indicated in the following argument of a dedicated gillnet fisherman: "I don't understand why they accuse us gillnet fishermen of overfishing [aalisapilunneq]. We only catch that we can sell [due to the catch specificity of the nets], whereas the longline fishermen also catch small fish that they have to discard. It is not we, but the longline fishermen that catch more fish than needed, and they are therefore guilty of aalisapilunneq".

However, the sea "pollution" discussed by the fishermen is not primarily a disturbance of an abstract, general environment. The problem is, rather, that the ghost-nets are thought to interfere directly with the Umwelt of the fish, understood in an Uexküllian sense as interfering with the fish's subjective understanding of its surroundings (Uexküll 1921; Ingold 1995). This was clearly stated by a fisherman who had just shifted from gillnets to longlines, allegedly on moral 


\section{Andreas Roepstorff}

grounds: "These lost nets keep fishing, and the fish don't like the smell [of untended nets with rotten fish]. If only we could ban the nets, the fish would again be evenly distributed in the fjord". In a similar vein, a passionate longline fisherman stated: "These nets there is also a lot of pollution. Sometimes the nets drift into the icebergs, and then they can not find their nets, they just stand there somewhere. [...] The best fish are caught on longlines. They [i.e., the gillnet fishermen] only think about themselves. They don't think about the fish".

\section{Disturbing the seals}

Another important local environmental issues while I was doing fieldwork was the question of snowmobiles. In contrast to most other Arctic territories, the use of snowmobiles is heavily regulated in Greenland. In the area of Ilulissat, snowmobiles are only allowed in a narrow transport corridor along the coast. Elsewhere, the only allowed means of transportation is the dog sledge. In a fervent debate, it was argued that partly in concern for tourists, partly in concern for people without access to dog sledges, a wider use of snowmobiles should be allowed in the back country. The discussion was heated further by the arrival of a young Danish ecologist who attempted to introduce "sustainable tourism" in a Greenlandic context. He brought with him figures to prove how much pollution, in terms of emission etc., was produced by snowmobiles. The issue became tenser when a dispensation was granted to allow a film team to operate from a camp deep in the back country, which caused much snowmobile traffic for weeks. To complicate matters further, the film team had hired one of the strongest opponents of the snowmobiles, a Greenlandic tourist outfitter, as one of their consultants. To the strong displeasure of hunters and fishermen, this consultant thus moved around the back country on a large snowmobile. Rumors among the fishermen had it that during the filming, he did not dare to enter the fishing and hunting grounds alone, for fear of the consequences. The issue of the ban of snowmobiles was entangled in a latent ethnic and economical conflict (Dahl 2000: 236). Many temporary Danish occupants were unable to get into the back country since they do not have access to dog sledges and the tourist industry and the snowmobile rental were mainly in the hands of families that were not native Greenlanders. However, this was not how the discussion was framed. People mainly expressed concern for the ani- 
mals. According to the hunters, the problem was that the seals in Kangia were particularly shy, and snowmobiles would scare them away, which would interfere with the hunt. As in the issue of the ghost-nets, the main argument was not concern for the environment in an abstract sense. Rather, it was a matter of not interfering with the seals' Umwelt, since mediated by their inherent shyness, this would stop the interaction between men and animals. ${ }^{4}$

In both cases discussed so far, the underlying logic appears to be the same. The Greenlandic fishermen and hunters are concerned about their environment, and they claim that there is a clear relation between human behaviour and the availability of fish and seals. However, the relation is not the same as the one envisaged by most wildlife biologists or environmentalists. Fully in line with the basic idea that animals are sensing and thinking beings, the Greenlanders are concerned about not disturbing what they perceive as the animals' understanding of their environment (for a similar finding see Morrow \& Hensel 1992) . To use Uexküll's biosemiotic distinction, they are concerned with protecting the animals' Umwelt rather than protecting an abstract, general environment as it is characteristic of most environmentalists' and standard conservationists' approach. To a dualist, such as the early missionaries in Greenland or most contemporary environmentalists, this conception runs very close to an anthropomorphism that fails to distinguish between humans and nonhumans. However, this appears not to be the case. Rather, the conception is well in accordance with a 'traditional' Greenlandic understanding of humans and nonhumans, where the difference between humans and nonhumans is not a matter of the existence of a 'mind' or a 'soul,' but rather a question of humans being more than just body and mind (soul). My claim is not that Umwelt protection is generally a better strategy than environmental protection. It is quite clear from my research (Roepstorff 2000) and from similar evidence elsewhere in the Arctic (FienupRiordan 1990) that although many hunters and fishermen are very

${ }^{4}$ It is tempting to see a parallel between the alleged shyness of the seals and the concepts of taqippoq, tarneq and takar discussed above (note 3). In contemporary Greenland, sealing is still very much affiliated with maleness. This connection is inscribed in the language, where the words angut, 'man', and anguvoq, 'to catch a seal', are derived from the same root. Fieldwork evidence suggests that the spring hunt for seals in Kangia is indeed not just a matter of proteins, and Greenlanders with various ordinary jobs take some days off to participate together with professional hunters and fishers. The hunt may involve a ritual-like communal sharing of raw heart, liver, and blubber from a newly shot seal. 


\section{Andreas Roepstorff}

concerned with how human behaviour interacts with the Umwelt of particular species (that again, is related to the particular mind, or perhaps shyness of a given species), not much attention is being paid to whether fishing or hunting reduces the numerical stock, that is, the abstract, total body of all the specimens out there. In other words, it is as if both focusing exclusively on Umwelt protection and focusing exclusively on environmental protection foreground one aspect only while backgrounding other aspects that are rendered opaque. The integration of a perspective "from within" and "from without", a focus on Umwelt and a focus on environment, appears to be one of the most important challenges facing contemporary attempts to outline a human ecology that, like ecosemiotics, is both concerned with meaning and matter (Kull 1998a, 1998b; Hornborg 1996).

\section{Conclusion}

I began this essay by adopting Claude Lévi-Strauss's metaphor of "thinking with animals". As with all other structures identified by Lévi-Strauss, totemism and other religious ideas are the outcome of the particular way human minds try to understand the word. In doing so, "the mind operates in ways that do not differ in kind from those that have unfolded in the world since the beginning of time" (LéviStrauss 1972: 119). Lévi-Strauss refuses to uphold any particular mental difference between modern and primitive societies. This refusal of a particular mental dichotomy between moderns and primitives, between myth and science (Scott 1996), has become increasingly important in contemporary anthropological theory. However, in the case of Lévi-Strauss, abandoning one dichotomy appears to involve a very high cost, namely the reinforcement of another dichotomy between nature and culture. Because he insists on this distinction being fundamental, "thinking with animals" becomes ultimately a question of "from within" rather than "from without".

Greenlandic fishermen appear to think with animals in a way very different from the one identified by Lévi-Strauss. It is not a question of using animals as more or less arbitrary resources for the embodiment of "speculative thought". Instead, they think along with animals, i.e., they use much more concretely ideas of how animals think about the world to get to know it, and this knowledge has consequences for the way they act in the word. 
These examples show that it is in the constructive interplay between the inside and the outside that animals are good to think with, and thinking with animals appears to reveal more than the general, abstract mechanisms of the mind. Resulting from a combination of specific ideas about the world and an interaction with that very world, the outcome of "thinking with animals" is a knowledge object that contains elements of both the world and of a particular way of knowing it. Ideally, then, studying these products may shed light both on the world and on the perception of it.

The relationship to animals is hence extremely interesting for anthropology, biosemiotics, and ecosemiotics. In my Greenlandic study, it appears that it is the perceived similarities between animals and people that allows humans to think with animals, just as it is the difference between animals and people that allows one to do different things to animals - eat them for instance. My most recent fieldwork has been in brain imaging laboratories, and it appears, in a similar vein, that it is the perceived similarities that allow one to think with animals, just as it is the perceived differences that allow one to treat them very differently. In the first case, it is the material similarity between humans and, say, a pig, that allows us to treat the pig body as an experimental model for human bodies. Similarly, it is the perceived difference (nonperson, no mind) that allows one to kill the pig in various ways solely for the purpose of acquiring knowledge about it and, by extension, about human beings.

This suggests that instead of maintaining a priori a sharp distinction between culture and nature, the more interesting issue is how, in a particular case, the borderline between "culture" and "nature" and between humans and nonhumans is drawn. It is not a question of seeing nature as either "really real" or "fully constructed and full of meaning". On the contrary, "nature" appears to be both at the same time, really real and completely semioticized. The interesting question is, therefore, to follow in detail how this comes about, how in one move, identities, competences and "natures" are distributed among humans and nonhumans. The shift from a classical biological perspective to a biosemiotic perspective is an interesting attempt to reconfigure the border between humans and nonhumans. If it is true that nonhumans, just as humans, rather than inert bodies, are mindful entities endowed with semiotic competence, the question remains: what is it, then, that separates humans from nonhumans? The traditional answer among the Inuits would be that this difference lies in the name and all that follows from it, an embeddedness in and an ability to create symbolic, 
social, and meaningful networks transcending the single individual. In strange ways, this idea is not entirely different from the claim in contemporary biosemiotics that it is indeed the symbolic faculty that renders people unique among the animals (Deacon 1997; Roepstorff 2001).

\section{References}

Berthelsen, Christian; Jakobsen, Birgitte; Kleivan, Inge; Nielsen, Frederik; Petersen, Robert; Rischel, Jørgen 1990. Gronlandsk Dansk Ordbog, Oqaatsit. Nuuk: Atuakkiorfik.

Dahl, Jens 2000. Saqqaq: An Inuit Hunting Community in the Modern World. Toronto: University of Toronto Press.

Deacon, Terrence W. 1997. The Symbolic Species: The Co-evolution of Language and Brain. New York: W.W. Norton \& Company.

Descola, Philippe; Pálsson, Gisli 1996. Introduction. In: Descola, Philippe; Pálsson, Gisli (eds.), Nature and Society: Anthropological Perspectives. London: Routledge, 1-19.

Fienup-Riordan, Ann 1990. Eskimo Essays: Yu'Pik Lives and How We See Them. New Brunswick: Rutgers University Press.

Hornborg, Alf 1996. Ecology as semiotics: outlines of a contextualist paradigm for human ecology. In: Descola \& Pálsson 1996: 45-63.

Ingold, Tim 1995. Building, dwelling, living: How animals and people make themselves at hone in the world. In: Strathern, Marilyn (ed.), Shifting Contexts: Transformations in Anthropological Knowledge. London: Routledge, 57-80.

- 2000. The Perception of the Environment. London: Routledge.

Kirmayer, Laurence J. 1988. Mind and body as metaphors: Hidden values in biomedicine. In: Lock, Margaret; Gordon, Deborah (eds.), Biomedicine Examined. Dordrecht: Kluwer, 57-93.

Kull, Kalevi 1998a. On semiosis, Umwelt and semiosphere. Semiotica 120(3/4): 299-310.

- 1998b. Semiotic ecology: Different natures in the semiosphere. Sign Systems Studies 26: 340-370.

Lakoff, George; Johnson, Mark 1980. Metaphors We Live By. Chicago: Chicago University Press.

Latour, Bruno 1993. We Have Never Been Modern. New York: Harvester Wheatsheaf.

Lévi-Strauss, Claude 1963. Totemism. London: Beacon Press.

- 1972. Structuralism and ecology. In: Lévi-Strauss, C., The View from Afar. London: Penguin, 101-120.

Morrow, Phyllis; Chase, Hensel. 1992. Hidden dissension: Minority-majority relationships and the use of contested terminology. Arctic Anthropology 29: $38-53$. 
Nuttall, Mark 1992. Arctic Homeland: Kinship, Community and Development in Northwest Greenland. London: Belhaven.

- 1998. States and categories: Indigenous models of personhood in Northwest Greenland. In: Jenkins, Richard (ed.), Questions of Competence: Culture, Classification and Disability. Cambridge: Cambridge University Press, 176193.

Rink, Hinrich 1974 [1875]. Tales and Traditions of the Eskimo: With a Sketch of Their Habits, Religion, Language and Other Peculiarities. London: C. Hurst \& Company.

Roepstorff, Andreas 1998. Virtual stocks, experts and knowledge traditions. In: Dorais, L.J.; Nagy, M.; Müller-Wille, L. (eds.), Aboriginal Environmental Knowledge in the North. Quebec: GETIC, Université Laval, 95-122.

- 2000. The double inter-face of environmental knowledge: Fishing for Greenland Halibut. In: Neis, B.; Felt, L. (eds.), Finding Our Sea Legs: Linking Fishery People and Their Knowledge with Science and Management. St. Johns: ISER Books, 165-188.

- 2001. Brains in scanners: An Umwelt of cognitive neurosicence. Semiotica 134(1/4).

- 2002. Clashing cosmologies: Contrasting knowledges in the Greenlandic fishery. To appear in: Roepstorff, A.; Bubandt, N.; Kull, K. (eds.), Imagining Nature. Practices of Cosmology and Identity.

Roepstorff, Andreas; Bubandt, Nils 2002. Introduction: The critique of culture and the plurality of nature. To appear in: Roepstorff, A.; Bubandt, N.; Kull, K. (eds.), Imagining Nature: Practices of Cosmology and Identity.

Scott, Colin 1996. Science for the West, myth for the rest? The case of James Bay Cree knowledge construction. In: Nader, Laura (ed.), Naked Science: Anthropological Inquiry into Boundaries, Power and Knowledge. New York: Routledge, 69-86.

Sebeok, Thomas A. 1988. 'Animal' in biological and semiotic perspective. In: Ingold, Tim (ed.), What is an animal? London: Routledge, 63-76.

Uexküll, Jakob von 1921. Umwelt und Innenwelt der Tiere. Berlin: Springer.

\section{Думая вместе с животными}

Центральным утверждением биосемиотики является приписывание семиотической компетенции и другим существам кроме человека. По странным историческим причинам это утверждение в "нормальном" биологическом дискурсе часто оспаривалось. При анализе этнографического материала Гренландии оказывается, что люди относятся там к животным как к “личностям", т.е. чувствующим и думающим существам. Считается, что животные, как и люди, имеют знания о среде своего обитания. Признание такой семиотической компетенции в качестве бесспорного факта позволяет искусным рыболовам и охотникам опираться не только на свою интерпретацию окружающей среды, но и 
на интерпретацию ее животными. Поведение рыб, тюленей и других животных, обусловленное их семиотической компетенцией, можно, таким образом, интерпретировать как приписывание ими значения поведению, например, китов и айсбергов. Подобное априорное присуждение семиотической компетенции проявляется и в спорах по поводу управления и регулирования численности животных. Большая часть дискурса рыболовов и охотников не столько посвящена вопросу о том, "на исходе ли запасы", сколько сосредотачивается вокруг вопроса, могут ли животные быть семиотически дезориентированы действиями человека.

\section{Mõeldes koos loomadega}

Biosemiootika keskseks väiteks on semiootilise kompetentsi omistamine veel teistelegi olenditele peale inimese. Kummalistel ajaloolistel põhjustel on see väide olnud "normaalses" bioloogilises diskursuses tihti vaieldav. Gröönimaa etnograafilise materjali analüüsist ilmneb, et inimesed suhtuvad seal loomadesse nagu mitteinimestest "isikutesse", ehk nagu tundvatesse ja mõtlevatesse olenditesse. Arvatakse, et loomad nagu inimesedki omavad teadmisi oma elukeskkonna kohta. Suhtumine sellisesse semiootilisse kompetentsi kui ilma igasuguse kahtluseta fakti võimaldab osavatel jahi- ja kalameestel toetuda mitte üksnes enda interpretatsioonile oma keskkonnast, vaid ka loomade interpretatsioonile oma keskkonnast. Kalade, hüljeste ja loomade käitumist, mis on tingitud nende tunnustatud semiootilise kompetentsi poolt, võib seega interpreteerida kui teadete andjat, näiteks vaalade ja jäämägede käitumise kohta. Selline semiootilise kompetentsi a priori omistamine ilmneb samuti saakloomade reguleerimise ja majandamise alastes vaidlustes. Ei arutleta mitte niivõrd selle üle, kas "varud on ammendunud", vaid suur osa kala- ja jahimeeste diskursusest keskendub pigem küsimusele, kas loomad võivad olla semiootilistelt häiritud inimeste tegevusest. 